\title{
Beta testing in diabetes
}

\section{By Steve Edelson, Executive Editor}

Conventional wisdom holds that the only way to generate new islet cells in people with type 1 diabetes is through cell therapy. A trio of recent deals, however, suggests that some companies and not-forprofit organizations are betting on a different approach. All three collaborations involve the use of small molecules or peptides to accomplish the task of making more insulinproducing cells.

First, a March deal between the Juvenile Diabetes Research Foundation International (JDRF), Pfizer Inc., Hadassah Medical Organization and The Hebrew University of Jerusalem will screen undisclosed small molecules from the pharma company for the ability to replicate and regenerate $\beta$ cells. The two Israeli institutes will carry out the screens, and JDRF and Pfizer will provide research funding.

This month, CureDM Inc. granted sanofi-aventis Group exclusive worldwide rights to Pancreate proisletide, a peptide that stimulates the formation of pancreatic islets of Langerhans, the structures containing the pancreas' endocrine cells, including $\beta$ cells. CureDM could receive as much as $\$ 335$ million, plus tiered royalties.

Also in April, Fate Therapeutics Inc. acquired Verio Therapeutics Inc. for an undisclosed sum. Verio's pipeline includes compounds that promote the growth of new insulin-producing $\beta$ cells.

Although the goal of all three deals is to eliminate or at least reduce the need for complex cell therapies, such approaches still will require complementary therapeutics that halt the underlying autoimmune siege on insulin-producing cells.

\section{Next-generation regeneration}

JDRF's four-way deal was triggered by a 2007 paper in The Journal of Clinical Investigation showing that the few $\beta$ cells remaining in mice after induction and then reversal of a diabetes-like state actually had the capacity to regenerate. ${ }^{1}$

The model involved using doxycycline as a switch to turn on the production of diphtheria toxin in $\beta$ cells of transgenic mice, resulting in apoptosis, destruction of the islet architecture and diabetes. When the animals were taken off doxycycline, their blood glucose levels normalized and $\beta$ cells regenerated.

The team that developed the mouse model was led by Yuval Dor, pro- fessor in the Department of Cellular Biochemistry and Human Genetics at Hebrew University. The work was partially funded by JDRF.

After publication of the JCI paper, JDRF "had a joint call with Pfizer and the academics and developed a research plan where we'd work together to evaluate Pfizer's compounds for their effects on $\beta$ cell recovery," said Patricia Kilian, regeneration program director at the foundation.

"The finding that adult $\beta$ cells are capable of replicating gave another potential avenue for replenishing $\beta$ cells" instead of just cell therapy, said Benjamin Glaser, professor of endocrinology at Hadassah. Glaser, whose group will be working on screening the Pfizer molecules, is focused on the mechanisms of $\beta$ cell regulation and formation.

Glaser noted that small molecules should have advantages over cell therapies in treating type 1 diabetes. "When you do cell therapy, you're going from a stem cell or another differentiated cell into an insulin-producing cell," he said. "There are a lot of potential complications that can arise, such as the potential for tumorigenicity."

Another issue with cell therapy, noted Glaser, is "getting the cells to do the whole job-secreting insulin, but in a semiregulated manner. In contrast, our approach is taking real, live, functioning $\beta$ cells and ramping up their own innate mechanisms for replicating."

The parties declined to disclose the specific types or targets of molecules they plan on screening.

\section{Minding the INGAP}

According to CureDM cofounder Loraine Upham, the company's Pancreate goes a step beyond growing $\beta$ cells and instead promotes the growth of islets.

" $\beta$ cells just outside an islet will make insulin, but they don't respond to glucose," she noted. "Although $\beta$ cells make up $85 \%$ of an islet and are clustered in the middle of it, the surrounding cells in the islet are critical for insulin secretion. The control mechanism is critical."

Pancreate's origins date to the 1980s, when researchers at Eastern Virginia Medical School and McGill University were developing a hamster model of pancreatitis. As a side observation, they noted that the animals were producing many islets, which led them to ask what was stimulating that growth. They eventually found a protein called islet neogenesis associated protein (Ingap). ${ }^{2}$

The development of INGAP has changed corporate hands many times, and suffered a setback in 2002 when Procter \& Gamble Co. dropped the compound on the heels of negative Phase II data. Exsulin (INGAP peptide), a synthetic version of a portion of Ingap, now is being developed by Exsulin Corp.

"We saw promise in Ingap and I then asked whether the human sequence might work better," said Upham. CureDM identified the human homolog of the protein in 2005 and homed in on the bioactive piece. 


\section{ANALYSIS}

One of the key problems with this work, according to Upham, was that there was never further work done to stabilize the natural protein. Thus, CureDM spent about a year working on ways of stabilizing its peptide, Pancreate. Now, said Upham, "proteases in serum that would degrade the vast majority of proteins leave our molecule untouched."

Pancreate is in preclinical development for types 1 and 2 diabetes.

\section{Addressing autoimmunity}

Fate Therapeutics is not discussing the specifics of the preclinical stem cell modulators it gained through the acquisition of Verio. But it is clear that any company seeking to regrow $\beta$ cells will need to address the other half of the equation: the immune system's assault on insulin-producing cells.

"The key in patients will be blocking autoimmunity," Upham told SciBX. "If not, the new islets will get chewed up just as fast as the old ones. If we can't block autoimmunity, type 1 patients won't benefit from Pancreate" or from compounds that regenerate $\beta$ cells

A key target of therapies aimed at arresting autoimmunity is CD3. Antibodies against CD3 from MacroGenics Inc. and Tolerx Inc. are in Phase II/III and Phase III testing for type 1 diabetes, respectively. MacroGenics' teplizumab (MGA031) is partnered with Eli Lilly and Co., and Tolerx's otelixizumab (formerly TRX4) is partnered with GlaxoSmithKline plc.

\section{PUBLIC-PRIVATE INTERFACE}

CD3 is a protein that is part of the T cell receptor complex and is involved with $\mathrm{T}$ cell activation. Blocking the target, therefore, should stem the attack of $\mathrm{T}$ cells on host tissues.

Edelson, S. SciBX 3(17); doi:10.1038/scibx.2010.515

Published online April 29, 2010

\section{REFERENCES}

1. Nir, T. et al. J. Clin. Invest. 117, 2553-2561 (2007)

2. Rafaeloff, R. et al. J. Clin. Invest. 99, 2100-2109 (1997)

COMPANIES AND INSTITUTIONS MENTIONED

CureDM Inc., Wilmington, Del.

Eastern Virginia Medical School, Norfolk, Va.

Eli Lilly and Co. (NYSE:LLY), Indianapolis, Ind.

Exsulin Corp., Minneapolis, Minn.

Fate Therapeutics Inc., San Diego, Calif.

GlaxoSmithKline plc (LSE:GSK; NYSE:GSK), London, U.K.

Juvenile Diabetes Research Foundation International, New York, N.Y. Hadassah Medical Organization, Jerusalem, Israel

The Hebrew University of Jerusalem, Jerusalem, Israel

MacroGenics Inc., Rockville, Md.

McGill University, Montreal, Quebec, Canada

Pfizer Inc. (NYSE:PFE), New York, N.Y.

Procter \& Gamble Co. (NYSE:PG), Cincinnati, Ohio

sanofi-aventis Group (Euronext:SAN; NYSE:SNY), Paris, France

Tolerx Inc., Cambridge, Mass.

Verio Therapeutics Inc., Ottawa, Ontario, Canada 